This article was downloaded by: [CDL Journals Account]

On: 25 June 2009

Access details: Access Details: [subscription number 912375045]

Publisher Routledge

Informa Ltd Registered in England and Wales Registered Number: 1072954 Registered office: Mortimer House, 37-41 Mortimer Street, London W1T 3JH, UK

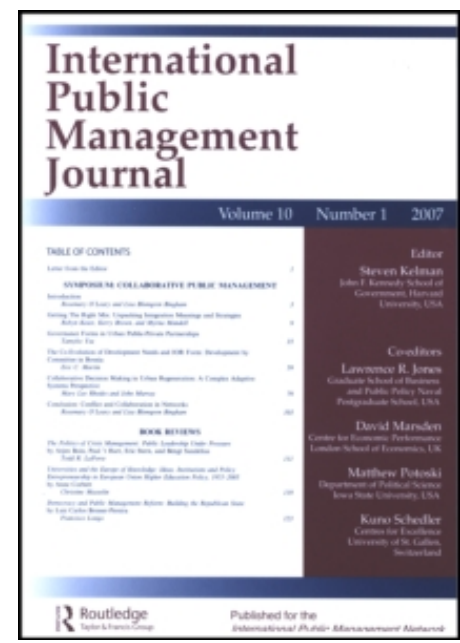

International Public Management Journal

Publication details, including instructions for authors and subscription information: http://www.informaworld.com/smpp/title content=t737963440

\title{
Generating Resources and Energizing Frameworks Through Inclusive Public Management
}

Martha S. Feldman a; Kathryn S. Quick a

a University of California, Irvine

Online Publication Date: 01 April 2009

To cite this Article Feldman, Martha S. and Quick, Kathryn S.(2009)'Generating Resources and Energizing Frameworks Through Inclusive Public Management', International Public Management Journal,12:2,137 - 171

To link to this Article: DOI: $10.1080 / 10967490902873408$

URL: http://dx.doi.org/10.1080/10967490902873408

\section{PLEASE SCROLL DOWN FOR ARTICLE}

Full terms and conditions of use: http://www.informaworld.com/terms-and-conditions-of-access.pdf

This article may be used for research, teaching and private study purposes. Any substantial or systematic reproduction, re-distribution, re-selling, loan or sub-licensing, systematic supply or distribution in any form to anyone is expressly forbidden.

The publisher does not give any warranty express or implied or make any representation that the contents will be complete or accurate or up to date. The accuracy of any instructions, formulae and drug doses should be independently verified with primary sources. The publisher shall not be liable for any loss, actions, claims, proceedings, demand or costs or damages whatsoever or howsoever caused arising directly or indirectly in connection with or arising out of the use of this material. 
International

Public

Management

Journal

\title{
GENERATING RESOURCES AND ENERGIZING FRAMEWORKS THROUGH INCLUSIVE PUBLIC MANAGEMENT
}

\author{
MARTHA S. FELDMAN AND KATHRYN S. QUICK \\ UNIVERSITY OF CALIFORNIA, IRVINE
}

\begin{abstract}
Resources are generally considered important for the practice of management. Potential resources, however, have to be put into use in order to fulfill their potential. In this paper, we use ethnographic research on the city budgeting cycle in Grand Rapids, Michigan, to explore the process of putting potential resources into use to energize desired frameworks as part of the practice of inclusive management.
\end{abstract}

\section{INCLUSIVE WAYS OF KNOWING AND RESOURCES}

The relationship between resources and participation is a frequent consideration of people implementing and studying public participation practices. This concern plays out in commonplace calculations among public managers about whether and how to engage in participation. Public managers often think of participation as eating up resources, such as staff energies, consulting services, citizen efforts, money, and time. Government agencies therefore try to use these resources responsibly, for example by providing an exchange of amenities (meals, parking, etc.) to complement citizens' contributions, or by carefully managing participation to maximize the benefits in terms of process and results. They may hope that it will generate good will and community support for a decision. Many agencies and community activists invest the time, budget, and energies that participation requires because they believe in participation's intrinsic value, perhaps because it is the hallmark of a democratic society, builds community, or is a route to community empowerment. Still, there are nagging doubts about participation's benefits, for example whether it wouldn't be cheaper, faster, or smarter to leave the decisions to expert agency staff or elected officials. Sometimes agencies implement participation because they have to, begrudging the resources invested because they do not expect to get much out of it. 
We do not contradict these understandings. However, we suggest that the relationship of participation and resources is more complex. Through a case study of community involvement in city budgeting, we explore a process identified as "resourcing" that connects the actions people take and the frameworks that are energized through those actions. We refer to this as an endogenous resourcing cycle, meaning that resources are not exogenous and fixed, but rather generated as they are brought into use. We direct our attention towards the practices to show how actions taken by managers and members of the community can make resources more and less available for certain frameworks for community engagement.

The resourcing cycle of actions-resources-frameworks that we theorize is a general dynamic. In this paper, we explore its link with inclusive management (Feldman and Khademian 2000; 2007). We illustrate how inclusive management operates as a particular way of knowing that enables public managers to recognize and intervene in resourcing in specific ways. In this context, we think of a way of knowing as a meta-framework for practices that orient sense-making and action. The ways of knowing concept is rooted in a dynamic understanding of knowing developed by organization theorists who use practice theories to understand organizational phenomena. These theorists build on the difference between knowing that and knowing how, and point out the importance of knowing as a dynamic and situated practice (Orlikowski 2002; Nicolini, Gherardi, and Yanow 2003; Nicolini 2007). As we describe below, the dynamic nature of a way of knowing is an important difference between our perspective and much of the theorization of schemas and frames, and for this reason we refer to inclusion as either a way of knowing or a meta-framework throughout this text.

Inclusive management consists of the efforts of public managers to facilitate inclusion in policymaking and implementation. Building upon prior research (Feldman and Khademian 2000; 2003; 2007; Quick and Feldman 2007), we characterize inclusive management by reference to three broad principles. First, inclusiveness involves bringing different perspectives to bear on issues. These perspectives are often defined as interests and may be associated with institutions, jurisdictions, or domains. Public participation is often used in the practice of inclusive management, though inclusiveness may also be practiced within organizations and across organizational, jurisdictional, or sectoral boundaries. While participation is clearly part of inclusion, the connection is not entirely straightforward, as the research on the effects of participation on organizational productivity shows. Though early on participation in itself was theorized as being salutary (Coch and French 1948; Morse and Reimer 1956; McGregor 1960; Likert 1961), over time scholars have found that participation is a relatively complex phenomenon (Vroom and Yetton 1973). A variety of factors, including management practices and ways of empowering people, can make participation more or less effective (Spreitzer 1996; Kirkman and Rosen 1999; Latham, Erez, and Locke 1988; Morrison and Milliken 2000; Spreitzer and Quinn 2001) and inclusive (Ely and Thomas 2001). Scholarship on deliberative democracy further supports the complex nature of the relationship between participation and inclusion (Rawls 1971; Benhabib 1996; Young 2000; Roberts 2004).

Accordingly, we suggest that two additional principles are essential to assessing the inclusiveness of practices. The second principle is that inclusion involves creating 
opportunities for differing perspectives to be engaged in a deliberative conversation in a way that makes it possible to generate new ways of thinking and acting. Consistent with research in organization theory, public management, and planning (Forester 1989; Healey 1997; Reich 1998; Innes and Booher 1999; Abers 2000; Young 2000; Ely and Thomas 2001; Thacher 2001; Feldman, Khademian, Ingram, and Schneider 2006), we note that practicing inclusion involves more than just seeking and aggregating or balancing multiple perspectives. It involves creating the potential for these perspectives to inform and influence one another, thereby generating new frameworks and possibilities for action.

Third, inclusion is expansive in ways reminiscent of Dewey's discussion of the development of democratic community (Dewey 1926/1988), Hook's conceptualization of a democratic community as a community of ongoing inquiry (Talisse 2001), Flyvbjerg's idea (1998) that democracy is not something a society has but something it must continuously work for, and Dryzek's notion (1990) of authentic democracy as a continual striving rather than as a state of being. Fung and Wright $(2003,22)$ call upon governments to institutionalize "perpetual participation" and avoid single-issue deliberation, and Healey (2003) observes that collaborative planning produces guidelines for ongoing community decision making, not merely a blueprint for plan implementation. Inclusion cannot be self-contained because it is never complete. It must, therefore, always refer to an ongoing stream of issues, the continuous development of a community of participation that engages with these issues, and the generation of new possibilities for people to work together on addressing public issues. Resourcing is intrinsic to the ability to manage inclusively because it links ideas or frameworks with actions and, thus, is integral to this expansive quality.

We begin with an explanation of resourcing and a review of its relationship to other literature on resources, including resources as they have been discussed in relation to participatory processes. We then describe our ethnographic methods and the Grand Rapids budgeting case, followed by an analysis of the case in terms of resourcing. We conclude with a discussion of the implications of our analysis for theorizing resources, the sociological literature on framing, and for practicing inclusive management.

\section{RESOURCING: BRINGING POTENTIAL RESOURCES INTO USE}

We adopt a notion of resources that focuses on how the things that we call resources are used as resources. In keeping with earlier work on this topic (Feldman 2004; Howard-Grenville 2007), we call this resourcing, or resourcing in practice, to denote the importance of practices that bring things into use as resources. From this perspective, the value of a resource is not a fixed property, but is dependent upon how it is used in relation to a particular framework. Actions people take link resources to frameworks, and this linkage both realizes the resource's value in that particular context and reshapes the framework. These actions may be intended to make this linkage or the linkage may be accidental or unconscious. Any action may resource multiple frameworks, in the process both creating new frameworks and activating old ones. As shown in Figure 1, this relationship between actions, resources, and frameworks is a recursive one in which actions on one side of the 


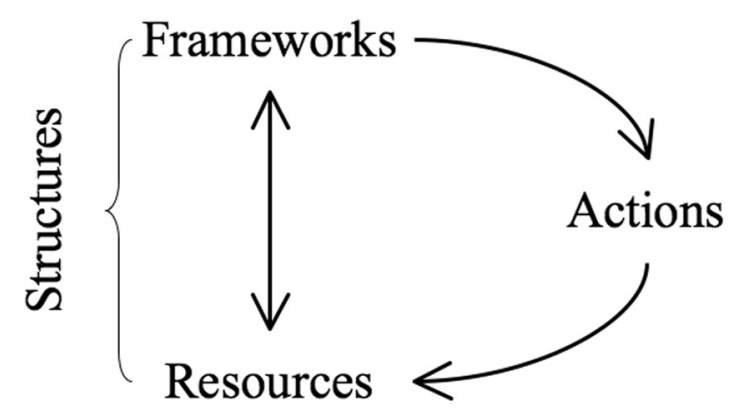

Figure 1. The Recursive Cycle of Structures (Comprised of Resources and Frameworks).

relationship affect and are affected by structures comprised of resources and frameworks acting in combination. Our analysis focuses attention on the actions that create potential resources and that link potential resources with frameworks in which they can be used.

In this view, it is helpful to distinguish between resources in use and potential resources. Objects, capacities, and qualities become resources when they are being used to energize - to resource - one or more frameworks. Otherwise, they are static things that have only potential. Regarding a potential resource as having innate value, exchange value, or a fixed use-value that is a permanent, embedded quality of the thing, implies that its value is conserved by not using it because its value is depleted by its use (Hobfall 2002). We instead suggest that to become resources, things or qualities have to be put into use, that they then realize context-specific values contingent upon how they are placed in use, and furthermore that putting them into use is not a zero sum proposition.

This conceptualization is similar to Orlikowski's $(1992 ; 2000)$ argument about technology. She argues that the materiality of technology is not determinative, but that what technology is becomes instantiated in practice. Like technology, any kind of resource may be used in ways that are entirely different from how designers, procurers, or others involved in their generation may have imagined (DeSanctis and Poole 1994; Orlikowski 1992; 2000). Computers can be used as plant stands, for instance, or bills of currency can be burned rather than used to buy goods and services. These are examples of unexpected uses of potential resources. A resource's potential may energize multiple frameworks, depending upon how it is used. "Wasting" time implies that we are not satisfied with the consequences of how time was used, pointing to the dynamic quality of value and use. A resource constraint in one framework may be a potential resource for another. Limited time for extended vacations may energize creativity in finding other kinds of recreation and refreshment.

We base our conceptualization of resources on structuration theory, a form of practice theory that conceptualizes a recursive, mutually constitutive relationship of action and structure (Giddens 1984), as shown in Figure 1. The duality of structure, in which structure is both medium and outcome, underlies the recursive relationship that we draw on. What this means is that action produces and reproduces structure 
(structure as outcome) at the same time that structure constrains and enables action (structure as medium). Within this theory, structure consists of rule-resource sets. We separate rule and resource to explore the dynamic nature of resources. We have substituted the term framework for rule, frame, or schema because its common sense use in the context we study fits the meaning of rule as it is used in structuration theory. ${ }^{1}$

We build upon structuration theory by calling out resources as an element of structure (Sewell 1992; Feldman 2004; Howard-Grenville 2007), thus allowing us to see the integral role of resources more clearly as well as the relationship between action and resources. Actions potentially create one or more resources as they energize one or more frameworks for further action. From this view, actions taken and frameworks enacted are consequential because they define the resource. Frameworks, actions, and resources are not in a one-to-one relationship (Sewell 1992). The multiplicity of structures and actions creates opportunities for bringing new actions, resources, and frameworks into any particular recursive relationship. As we analyze our case, we depict this creativity in the form of a cascading dynamic with action spilling over to produce resources, resources pouring out to enact one or more frameworks, and frameworks enabling further actions. The resourcing dynamic means that the actions we take contribute energy to frameworks in the form of resources. This perspective complements other scholarship that utilizes structuration theory to study the co-constitution of power in public managers' actions and the structures they enact or change (Forester 1989; Healey 2003).

Our perspective on resources is in contrast with the traditional view of resources defined as specific kinds of assets or qualities. The political economy model (Zald 1970; Wamsley and Zald 1973), the power-dependence model (Thompson 1967), and the resource dependency theory literature (Pfeffer and Salancik 1978; Pfeffer 1982) have all identified resources as important exogenous factors that organizations could use more or less well, but not necessarily generate. More recently, the resourcebased view (Wernerfelt 1984; Barney 1991; 2001; Bryson, Ackerman, and Eden 2006) and dynamic capabilities perspective (Teece, Pisano, and Shuen 1997; Eisenhardt and Martin 2000) have identified resources as internally generated. Nonetheless, with rare exceptions (Leblebici, Salancik, Copay, and King 1991; Feldman 2004; Howard-Grenville 2007), resources are considered to have inherent value in their own right, or value for obtaining things with inherent value (Hobfoll 2002). Even people who have adopted the structuration lens have tended either to combine resources with schemas as the structural side of the structure-agency cycle or to associate resources with materiality and, thus, separate them from the more dynamic and volatile features of structure (Sewell 1992).

Thus, while recognizing the value of defining resources broadly to include moral, cultural, organizational, and human as well as material resources (Edwards and McCarthy 2004), our concern is not what constitutes a resource. We accept anything as a potential resource. The question of interest becomes how we turn something from a potential resource into a resource in use. We focus our attention on practices rather than things. This orientation does not overwrite practical concerns about what constitutes a resource, what it is worth, how to get more out of a resource, how to deal 
with diminishing resources, or the distribution of access to resources. It does, however, recast these concerns in a more dynamic, perhaps more liberating, context.

\section{RESOURCES AND PARTICIPATION}

Resources have long been a theme in the literature on public participation in government, of which inclusive management is one form. Most of the literature reflects the notion that resources are fixed and external to participation. Participation, for better or worse, acts on fixed resources by consuming them, contributing to them, or allocating them. We look at these in turn, beginning with how participation consumes resources. Civic engagement consumes agency budgets, staff and volunteer time, technical assistance, or information infrastructure (Aleshire 1970), and may not yield sufficient benefits in exchange for this investment (Delli Carpini, Cook, and Jacobs 2004; Koontz and Johnson 2004). Government staff time and funds expended in participation might better be used in implementation (Irvin and Stansbury 2004), reflecting a zero-sum view of resources. Furthermore, participation may limit the efficient and effective allocation of government resources, for example by curtailing staff members' ability to analyze problems neutrally, reach decisions promptly, or mobilize government services responsively (Rossi 1997; Simonsen and Robbins 2000).

Participants contribute resources to decision making as well. These resources include new information, self-interest, motivation to address problems, and new ways of knowing the issue (Aleshire 1970; Renn, Webler, Rakel, Dienel, and Johnson 1993). These can be used to generate better decisions and buy-in and limit delays, mistakes, and lawsuits (Aleshire 1970; Moynihan 2003; Grisez Kweit and Kweit 2007). Civic engagement may come at some political and material cost to participants, so that they weigh the perceived costs and benefits in deciding whether to take part (Klandermans 1984). Reflecting an exchange view of resource investment and outcomes, some agencies try to compensate for participants' expenses and opportunity costs, for example by providing childcare and meals at meetings, or to reduce the costs of participation through Internet-based media (Klein 1999; Eschenfelder 2004). Members of the public possess the resources for participation in different amounts, however. Individuals of higher socioeconomic status are more likely to have the requisite time, money, and civic engagement skills (Beard 2005; Brady, Verba, and Schlozman 1995) or Internet access (Krueger 2002). Those with greater individual and collective social capital are more engaged (Jenkins 1983; Verba, Schlozman, Brady, and Nie 1993; Bekkers 2005). Thus, a central concern of the participation literature is how to level the field to provide fairer access to participation (Forester 1989; Coelho 2004).

Another theme of the relationship between participation and resources considers how participation influences the allocation of government resources. One of the original arguments for participation is that it is a particularly good way to decide how to utilize limited public resources, such as government budgets and services (Roberts 1997; Abers 2000; Simonsen and Robbins 2000; Souza 2001; Guerra 2003). Early literature on community empowerment identifies participation as a 
key mechanism for redistributing community resources more equitably (Dahl 1961; Waste 1986, 17, citing Polsby 1980). Increasingly, however, scholars challenge whether public participation is preferable to agency's expert decision making in terms of workable, efficient, or just management of common resources such as environmental amenities and hazards (Kumar 2002; Bradshaw 2003) and healthcare (Richardson and Waddington 1996). Nonetheless, the degree to which local citizens maintain control over the allocation of government resources is considered an important indicator of democratic participation (Diamond and Tsalik 2001), though for such participation to be meaningful, governments must have sufficient resources to follow through on implementation (Schneider and Ingram 1997; Curtis 1998; Goldfrank 2007).

The above ideas conceptualize resources as fixed entities that are antecedent to participation and consumed by, contributed to, or divvied up by civic engagement. However, participation is also understood to generate new resources for communities. They may include improved projects and policies, new ways of understanding problems, or enhanced government - community trust (Aleshire 1970, Moynihan 2003). Several scholars have found a recursive relationship between community engagement and community capital (Lake and Huckfeldt 1998; Green and Haines 2002). Others have found that civic engagement provides an infrastructure for taking ongoing action (Minkoff 1997) or for transforming one sort of resource into another-for example, changing participants' individual viewpoints into a resource for building relationships, new understandings, and validity as a collaborative effort (Innes and Booher 1999) — that may be as important as specific policy decisions in addressing public issues.

Two studies document the endogenous production of community resources through participatory budgeting, also the subject of our case. Roberts (1997) observed a school district superintendent who fostered an extensive deliberative process about funding problems that generated new information and possibilities, community trust, and a budget that was readily approved and implemented. Describing participatory budgeting in Porto Allegre, Brazil, Abers $(2000,17)$ found "the civic mobilization sparked by the budget policy began to grow into a social force of its own," with neighborhood groups developing new reciprocal relationships and participants coming to broader understandings beyond their initial individual positions. These indications of endogenous resource generation are of particular interest to us, as they suggest that choices about how to implement participation can generate potential resources for governance.

\section{DATA GATHERING AND METHODS}

This paper addresses a gap in the literature on resources and public participation, namely the absence of a discussion of resourcing dynamics in participation. Our questions about the role of resourcing in public management have arisen out of an inductive process based upon long-term ethnographic research with public managers in Grand Rapids, Michigan, since 1998. Over this period, we have discerned a pattern of inclusive management. On some occasions, however, the 
managers have made decisions that the public does not perceive as inclusive, resulting in community anger, which has surprised the managers. The managers in turn saw the anger not as something to shy away from, but acknowledged it and engaged it in ways that restored inclusion. We describe these events in the account of the case below. Observing these dynamics has led us to questions about how public managers sustain inclusive management as a framework, how inclusive management operates as a way of knowing that guides actions, and how inclusive management affects public managers' perception and mobilization of potential resources. We analyze these dynamics in the analysis and discussion sections, following a thick description of the case.

Utilizing data gathered between 1998 and 2007, we focus on several public processes designed to address a city budget crisis. We observed community meetings and toured neighborhoods with community and business association organizers. We reviewed texts, including committee meeting minutes, staff reports, city and neighborhood plans, community organizations' websites and brochures, and radio and newspaper media coverage relating to the government decisions and processes about the budget. We interviewed 43 study participants (all identified by pseudonym) in 103 confidential, unstructured interviews, including 51 interviews with 24 persons regarding the unfolding budgeting crisis (Table 1).

One or both of the authors conducted the interviews with individuals or groups, in person or over the telephone. The interviews about the budget process were all recorded with the permission of the participants and transcribed. We identified potential participants through references from other study participants, observing community meetings, and reviewing meeting minutes and media coverage. Community members, consultants, and foundation members were interviewed once or twice each about their involvement in specific aspects of the budgeting process. Many of

TABLE 1

Characteristics of Participants in the Entire Study and in the Budgeting Subset

\begin{tabular}{|c|c|c|c|c|c|}
\hline & & \multicolumn{2}{|c|}{ Budgeting Cycle } & \multicolumn{2}{|c|}{ Entire Study } \\
\hline & & Persons & Interviews & Persons & Interviews \\
\hline $\begin{array}{l}\text { Community } \\
\text { member }\end{array}$ & $\begin{array}{l}\text { Community association } \\
\text { members, activists, } \\
\text { businesspeople, individuals }\end{array}$ & 16 & 23 & 20 & 28 \\
\hline $\begin{array}{l}\text { Senior city } \\
\text { manager }\end{array}$ & $\begin{array}{l}\text { City Manager team, city } \\
\text { department heads, city } \\
\text { division heads }\end{array}$ & 4 & 18 & 11 & 40 \\
\hline City employee & $\begin{array}{l}\text { Non-management city } \\
\text { employees }\end{array}$ & 2 & 11 & 10 & 54 \\
\hline Other & $\begin{array}{l}\text { Consultant, foundation, or } \\
\text { media observers or sponsors }\end{array}$ & 2 & 3 & 2 & 3 \\
\hline All informants & & 24 & 49 & 43 & 103 \\
\hline
\end{tabular}


the study participants who are city senior managers and other city employees were interviewed three to six times during the budgeting cycle in order to glean more information about the various efforts the city government undertook to address the funding crisis. The greater number of interviews with city staff allowed us to analyze the budgeting processes in the context of an unfolding series of public problems and public management experiments undertaken over the longer period; three city staff members involved in the budgeting cycle have been interviewed at least eighteen times each since 1998.

We conducted unstructured, active interviews (Holstein and Gubrium 1995; Spradley 1979; Anderson and Jack 1991) in which we engaged the study participants not only in accounts of what they observed or experienced, but in sharing their interpretation of those events. They expressed their opinions or feelings about a process, explained what might have been done better, or stated why they were dissatisfied or satisfied. Interviews began with simple questions. In initial interviews we asked the informant to describe their participation in the budgeting process, and on repeat interviews began with asking what had elapsed in the interim. When they began to talk about general feelings or observations of the budgeting process, we asked for specific examples of something that had made them satisfied or dissatisfied with the budgeting process. Then the interviewer(s) and informant(s) worked through interpretations of the events together.

Data were analyzed using standard coding, categorizing, and memoing techniques (Glaser and Strauss 1967; Strauss and Corbin 1990; Emerson, Fretz, and Shaw 1995; Lofland and Lofland 1995). We then interpreted this information through a variety of methods to expose different facets of the data-including semiotic (Feldman 1995), narrative (Czarniawska 2004; Feldman, Sköldberg, Brown, and Horner 2004), networked narrative (Pentland and Feldman 2007), dramaturgical (Abbott 2004), and ethnomethodological frameworks (Garfinkel 1967; Heritage 1984). These methods allowed us to question some of the assumptions embedded in the ways information was presented to us and to draw our attention to key events and processes, and provided the background for the analysis presented in this paper. We identified what aspects of the budgeting processes to focus on-the differences among their designs for participation, and the strong reactions to them-began to recognize the importance of resourcing dynamics occurring in that process, and moved on to the resourcing analysis found here.

Three features of the data are particularly important for our research. First, to a large extent, they allow us to understand the insiders' or emic perspective. The emic perspective is important to ensure against imposing interpretations on events that would not make sense to insiders (Goodenough 1970; Geertz 1973; Miller and van Maanen 1979; Agar 1986; Emerson et al. 1995). Second, these data provide us with many different insider perspectives. They allow us to triangulate in the sense that our interpretations can be informed by a number of ways of seeing the events (Denzin 1978; Altheide and Johnson 1994; Janesick 1994; Yin 2003). Third, the data are longitudinal, allowing us to follow events over long periods of time, pursue new lines of inquiry that emerge during the research, take a process-based view, and analyze the flow of actions, resources, and frameworks that occurred in this particular setting 
(Mohr 1982; Eisendhardt 1989; Sewell 1996; Langley 1999). Together, these aspects of the data allow us to thickly describe a setting, enhancing the validity of our interpretive analysis and inductive theory development (Glaser and Strauss 1967; Geertz 1973; Kirk and Miller 1986; Lin 1998; Locke 2001; Yanow and SchwartzShea 2006).

\section{THE CASE}

Grand Rapids is a Midwestern American city with a population of 195,000 in a metropolitan area with a population of $1,089,000$ in 2003, the midpoint of our study period. Founded in 1831, the city's location on the Grand River (a major transportation arterial for access to the American frontier), ample lumber resources, and rapid population growth made Grand Rapids the self-proclaimed "Furniture Capital of America" for almost 100 years. The furniture was made by ethnically, linguistically, and religiously diverse laborers, primarily recent immigrants, who tended to settle in relatively homogeneous neighborhoods that are still recognizable today. Although furniture began to lose importance in the early 1980s, manufacturing continued to dominate the local economy at least through the 1990s. Recently there has been large-scale private investment in health services and medical research and development. Several charitable foundations established by local businesspeople support community development, recreation, and arts programs.

The city's economy and population have continued to grow even since Michigan's overall growth began to stagnate in the 1970s. The state's second largest city after Detroit, Grand Rapids plays an increasingly important role in the state's economic, social, and political development (Kaldecek 1996; Carron, Ames, Kleiman, and Lefever 1998; LaMore and Supanich-Goldner 2000). In the 2000 census, $67 \%$ of residents identified themselves as white, 20\% as African American, and 13\% as Hispanic. Approximately 10\% were foreign-born, and over half had moved to their current residence within the previous five years. Less than one quarter of adults had a bachelor's degree, one in six lived below the poverty level, and the median household income was $\$ 37,444,83 \%$ of the state household median.

\section{Building Inclusive Management in Grand Rapids}

In terms of citizen participation, Grand Rapids' public agencies have had a mixed record. The school district's 1952 master plan for school desegregation alienated many in the community by shutting down a predominantly African American high school, arguably the strongest institution in the African American community, and bussing African American children long distances to predominantly white schools (Robinson 2006). In the 1960s and 1970s, city staff proposed to raze the city's historic neighborhoods. Incensed neighbors created the Heritage Hill Historic district, an important precedent for United States and Michigan historic preservation law, and now one of the community's proudest assets (Logan n.d.). A 1996 study of the city government identified the "minimal attention given to citizen participation" as one of the city's major shortcomings (Kaldecek 1996, 224). 
Over the period of our research, however, the city has been building inclusive management as a way of knowing. It has utilized more and less inclusive decisionmaking processes in many areas of government (Feldman and Khademian 2007; Quick and Feldman 2007). Around 1998 the city launched a process it refers to as Cultural Transformation in response to a consultant's report that described the organization as essentially dysfunctional with units working at cross-purposes. Top management provided support for a grassroots staff movement to transform the internal culture of the organization. One of the realizations that resulted was that the ability to provide service to residents was important to employees' self-worth. Three Community Oriented Government teams, each covering a different region of the city, were formed, comprised of community members and city staff. Over the years, the teams have strengthened relationships and problem-solved around nuisance animal control, graffiti, park revitalization, and gang violence, among other issues.

Concurrent with the introduction of Community Oriented Government, the city launched a process to write a new master plan. The prior master plans, completed thirty and fifty years before, had been the domain of planning staff who decided among themselves how the city plan should be changed. Senior management decided that this time the process should include more input from city residents, and hired a planner who excelled in inclusive processes. She worked closely with community members to design and raise funds from local foundations to support an intensive participatory process. Ultimately, Plan Grand Rapids involved hundreds of meetings and thousands of participants, and sailed through the City Commission approval process. To implement the plan, the city initiated another participatory process to involve area residents and businesses in revising the zoning ordinance, which was adopted in 2007 with widespread celebration and support.

Other collaborative efforts have ensued. These include partnerships of city staff, local colleges, and community organizations to promote lead poisoning prevention in a high-risk neighborhood and to successfully compete for a U.S. Department of Justice Weed and Seed grant. The city has engaged in collaborations with surrounding governments on animal nuisance abatement, optimizing first responder access by emergency fire and ambulance response across city boundaries, and sharing clean water and sewage treatment infrastructure. City management and labor unions have taken an interest-based bargaining approach to employment contract negotiations, and managers have sponsored public-private partnerships to find creative ways to encourage minority- and women-owned businesses.

Through these efforts, many people in Grand Rapids have learned more about how collaborations can work and how they can fail. Overall, the trend has been positive:

The cumulative result of community engagement experiments is that everyone expects that decisions will be reached inclusively. Residents expect to be involved in decision-making, residents want to be involved, and city staff and commissioners want residents' involvement (Rachel, senior city manager, 7/25/07). 
Community members assert that the city government "always wants involvement and input from the community" (Kylah, community member, 6/24/05) and that its senior managers are "totally committed to effective citizen participation" (Jenna, community member, 6/22/05). A city manager, disappointed that citizens do not participate even more, told us, "We try to involve the world, but you never can involve the world, people don't care. We do involve everybody who does care" (Joe, senior city manager, 8/11/06). Community expectations about being included have thus grown higher and higher over time, in part because city employees have deliberately seeded high expectations in order to achieve greater engagement. As one manager explained,

The more you engage, the higher the level of expectation about what you can deliver. There's a sense that if government kind of turns a deaf ear, people learn not to go there and have no expectations. But a city like us, that engages and has a lot of communication and accomplishes some things, encourages more of the same. So, the demands on a city that is truly caring, truly listening, and trying to be conscientious get greater and greater. Sometimes you say to yourself, "Look at all that we've accomplished! Why are you beating up on us, when in other cities nobody is even listening?" Well, it's because we are listening (Will, senior city manager, 8/11/06).

\section{Grand Rapids Budget Surveys}

Each year since Fiscal Year 2003 (FY 2003, July 1, 2002-July 30, 2003), the city of Grand Rapids has faced successively greater challenges balancing its annual budget, particularly in items funded through the General Operating Fund, which covered between $40 \%$ and $60 \%$ of all city expenditures over the study period. This fund originates from general tax receipts and funds many of the city's basic services, whereas other sources are earmarked for other parts of the budget. The city charter requires that one third of the General Fund be reserved for police and fire services, and the remainder is unrestricted. The budget shortfalls have resulted from a combination of a breakdown in the decades-long system of intergovernmental revenue sharing of taxes collected by the State of Michigan, rising costs of employee benefits, and decreased local income taxes.

The budgeting challenge first began to feel critical in planning for FY 2005, when the city had to cut $\$ 30$ million from its total $\$ 120$ million General Fund budget. Anticipating an additional \$11 million cut in FY 2006 that they imagined would translate into a cumulative loss of $25 \%$ of the city's total workforce from its FY 2002 levels, in 2005 the City Manager's office commissioned a survey to "get a clear idea about citizens' priorities ... for budget purposes and (to know) what outcomes they value the most" (Ian, senior city manager, 10/25/06). The management team hoped to obtain scientific information from the whole of the city's residents, not just rely upon the opinions of a smaller number of people who would care enough and be 
able to attend a community meeting. As one put it, "Well, you want the silent majority, you want to know what your citizens really think," not just opinions of the people who usually come to community meetings (Will, 8/11/06).

The survey was designed by a local university's community research unit and consisted of a series of questions about budgeting allocations. Researchers administered the anonymous survey by telephone to 759 randomly selected Grand Rapids households. They began by explaining that the city was facing an $\$ 80$ million budget deficit over the coming 5 years. Prefacing each question with the statement, "given the City's need to cut the budget," they then asked respondents whether they would prefer that the city stop, reduce, maintain, or increase funding for a series of 42 services. In the second phase, the city advertised a series of four community budget meetings around the city that were open to anyone interested. At these sessions, 132 participants used individual remote control devices to select the higher priority from sets of forced-choice pairs. Participants voted on pairings of 13 "critical outcomes" of city services - such as "well maintained streets" versus "a community that does not tolerate discrimination" - and voted separately on pairings of 15 types of budget allocations, such as "parks operation and maintenance" and "community policing" (City of Grand Rapids 2005). After the voting, which took up to 75 minutes, there was some limited time for discussion. The meetings were a more "raucous" process than the phone survey (Ian, 10/25/06), with some pairings prompting people in the audience to yell out angrily, "You can't choose between those two!" (Joe, 8/11/06) One participant later told us, "The tension in the room was intense, to say the least. I mean, one guy threw down his remote and refused to pick it back up" (Ben, community member, 10/20/06).

For both the telephone and community meeting data, the research institute then ranked the 42 service areas by order of priority, first weighting the results according to a number of demographic factors to try to make them more representative of the city's population as of the 2000 Census (Community Research Institute 2005). Everyone was satisfied that the data were statistically valid. The city manager and commissioners wanted to use the rankings to make budgeting choices that would be "reflective" of residents' priorities. The city's senior managers described the surveys as providing "great information" and the meetings as giving everyone who attended "a chance to register their opinion" (Will, 8/11/06). They proceeded to "budget according to those results" (Ian, 10/25/06), which were consistent with community surveys dating back to at least 2002 (Zoë, city employee, $1 / 30 / 06$ ), by interpreting low-ranked services as the first place to cut expenditures, given budget shortfalls. The city commissioners adopted the proposed budget by a vote of five to two.

But the city managers were soon to learn, "Even though we did a scientific telephone survey where we got really good results ... we couldn't bank on this being the genuine opinion of our citizenry" (Will, 8/11/06). Some community members and city commissioners vociferously protested that the surveys did not represent the community's real priorities. People were angry about the ranking system and some of the specific recommendations for eliminating or cutting back services that it produced. Though the adopted budget was based on a survey of city residents, 
the commissioners' decisions did not seem sensible or desirable to many of the members of the general public. By acknowledging that one choice was less important than another, people had not meant to imply that either was unimportant. Moreover, the way the information was gathered through forced-choice pairs at the community meetings violated their understanding of what knowledge they had to contribute. As one participant explained,

They would compare two things that people thought were equally important, but you had to choose one. Or they were ridiculous notions, like "Do you want to be safe or do you want to have good parks?" Well, we want both, but obviously safety comes first, so everyone would pick that. People couldn't speak their own mind about what they thought about stuff. There was a lot of willingness to speak out about what people found personally important or to highlight priorities that they wanted to preserve but weren't necessarily the top choices. But the way it worked out, if a choice wound up being one of the bottom ones, it seemed like you were giving an okay to cut it. And people weren't very comfortable with that (Ben, 10/20/06).

Following the preceding pattern of inclusive management in Grand Rapids described above, city residents had very high expectations about engaging in community decision making. Community members were frustrated that the budget survey was not more deliberative. A senior manager concluded, "It was a passive experience for our citizens. There wasn't enough time for them to talk at us, to look at us eyeball to eyeball.... The community was really unhappy that they didn't have their time to tell you what they think" (Will, 8/11/06). Participants thought they had more to contribute to budgeting than this process offered.

Several neighborhood organizations and some community members therefore put together a series of alternative public forums. One of the organizers complained about the budget surveys, "The city is not asking open-ended questions in this process...We feel the process needs to be much more open-ended" (Catalyst Community Radio show, 3/11/05). They intended the forums to facilitate more "authentic" feedback than the survey, which they felt had "pigeonholed" participants into predetermined, either/or choices (Ben, 10/20/06). The organizers therefore invited the public into a more open-ended process to consider what should be discussed about the budget and how. Some people had complained that the survey had been structured to force choices between services with ample, dedicated funding streams (e.g., water and sewage) with other programs that were dependent upon the General Fund. The forum participants therefore sought to educate themselves and the public so that they could make informed choices and to focus attention on the diminishing General Fund (Ben, 10/20/06). They formed a small task force with representatives from the city's three wards. In an iterative process, they surfaced questions through community meetings, went to city commissioners to research how budgeting related to those concerns, and reported and discussed the new information and questions at subsequent community meetings. 
Activists also sought to reframe the tenor of the budget discussion from viewing the city as a "charity case" to embracing its "assets" (Paula, community member, 5/31/06). "It seemed like the city was [saying], let's take away stuff that was the least important. And we were saying to flip-flop that and build a city that is attractive to people" (Ben, 10/20/06). The task force concluded by presenting an eight-point platform to the city commission that emphasized public participation and protecting community assets. Through the task force and on an individual basis, community members petitioned their elected officials to change their course of action on the budget, particularly to correct the use of the survey rankings to cut services. In particular, the decision to close the public swimming pools became a rallying point for oppositional community activism against the budget process and decision. The city commission ultimately ignored pools' low ranking in the survey and decided to open several of the pools for a shortened season.

\section{Grand Rapids Citizen Budget Advisors}

The next phase of this story took place the following year, when the city anticipated that another $\$ 11$ million in budget cuts would be required for FY 2006. The senior managers and commissioners recognized and publicly acknowledged that the community was angry about the previous year's process and the outcomes of the survey. They vowed to improve the process. To prepare the FY 2006 budget, they decided to appoint a residents' budget advisory group that would advise the city manager on the public participation process and specific budget recommendations. The city management team and city commissioners came up with a list of people to serve that specifically included the most vocal critics of the survey process. Senior managers explained that move in a broader context, telling us, "It is kind of our m.o. [mode of operation] to take the loudest complainers and bring them inside the tent" in order to "afford and give them responsibility" for helping to resolve the conflict (Will, 8/11/06) and to "arm them with better information" to generate better options together, or, if the oppositional dynamic and conflict cannot be resolved, to have a "better fight" that is more productive (Joe, 8/11/06).

Ironically, the advisors decided against additional public outreach. The 21 individuals who accepted the request to be Citizen Budget Advisors were diverse in terms of place of residence, income, race, ethnicity, affiliations (community organizer, business owner, etc.), and opinions about appropriate uses and sources of city funds (Gabriel, 5/8/06; Karen, 5/10/06; Alicia, 5/11/06; Fred, 5/31/06, all of whom are community members). For example, they were divided in their feelings about raising city taxes, labor unions, and subsidizing recreation for low-income residents. They decided that their diverse perspectives, the limited time, and the nearly endless supply of data about the budget that the managers had provided meant that they could achieve deeper deliberation and produce better decisions if they conferred more intensely among themselves than if they used their energies and time on organizing other public forums. Impatient with their facilitator for delaying their debating budgeting questions in favor of group-building activities, they dismissed her, appointed their own chair, and branched out into smaller groups 
to brainstorm options. They not only gathered opinions from their contacts in the community, but also turned their energies toward working through them together, coming up with new ideas and positions.

Very early on, the advisors turned aside from the expected path of making lineby-line budget recommendations and instead decided to come up with broad guidelines about budget allocations. This move was instigated by focusing on the question, "What kind of city do you want this to be?" There is some discrepancy about whether this was initially posed by someone from the city manager's office or an advisor, but everyone agrees that it was a key shift. As one participant explained, "We could have argued about which pool to close forever, but asking 'Do you want our kids to have a pool?' was an answerable question that let us move on" (Carla, 10/11/06). Rather than tackling line-by-line budget recommendations, the committee turned to articulating "foundational considerations" for budgeting choices. Presented with many hundreds of pages of budget information at their first meeting, they stripped the process down to providing guidelines for how to think about the budget, supplemented with suggestions about what to do with selected budget items.

In a brief final report, they recommended that the city use its budget to address the following "purposes of government": providing needed services that residents could not provide for themselves, addressing priorities articulated by the public, and promoting Grand Rapids as a desirable place to live, work, and conduct business. The quality of life framework for budget decision making enacted by the advisors enabled them to articulate broad principles about using the city's budget and staff, which the city manager and commissioners were able to use in adopting the budget. These principles emphasized promoting social equity, building long-term community assets to support a vibrant urban community, avoiding "symbolic cuts" to resolve the budget problem that would only damage morale, and taking a long-term view of budgeting priorities and constraints (City of Grand Rapids 2006, 4).

The public managers affirmed the legitimacy of the advisors as the leads on their own process and as co-authors of the city budget. They accepted the group's authority to dismiss the facilitator whom the city had contracted, and redirected their technical support towards helping the committee draft their position statement. They moved from having the complete management team attend each advisor meeting to having a single staff person as recorder and information conduit at subcommittee meetings. Finally, they changed tracks from supplying voluminous packets of budgeting information to providing tailored responses to the advisors' questions. Once the advisors produced their recommendations, the city managers took them to heart in their proposed budget, referencing the principles as guidelines for their decision making and making several specific budget line changes in accordance with them. The managers incorporated most of the few specific budget line item requests the advisors had made, including measures the managers found inadvisable and uncomfortable (Will, 8/11/06), such as reorganizing the city structure to eliminate some senior management positions. The City Commission adopted the proposed budget with a minimum of controversy. Notably, we have not heard any study participants, including people not involved in the advisors' process, criticize their process or its outcomes. This appears to validate the advisors' view that they possessed sufficiently 
diverse perspectives to generate a productive discussion among themselves that would be inclusive in terms of representing many points of view, providing opportunities for deliberation and discovering new options for action, and bridging with related groups and concerns in the community.

The implementation of the budget has been painful. As of FY 2007, the city had suffered cumulative cuts of $\$ 78.6$ million in the General Operating Fund since FY 2002 , accomplished in large part by reducing the city's total work force by 282 positions, a total of $25 \%$, including 80 sworn police and firefighter positions, and cutting back on parks and recreation maintenance and programs. City pools were kept open through $\$ 300,000$ in private donations. The overall budget picture is increasingly grim. The city manager points out that his transmittal letter for the FY 2008 recommended budget is "the most somber of his 20-year tenure" and urges the commission that "This is the absolute last year that we can use deficit funding. If we do not secure additional resources, we will slam into the wall of insolvency" (City of Grand Rapids 2007).

\begin{abstract}
ANALYSIS
Analyzing this case through the conceptual lens presented at the beginning of the paper allows us to bring forward certain parts of the story. In the following, we describe the flow of actions, resources, and frameworks through the budget process as it relates to two specific efforts to engage the community around budgeting: the survey and the advisors. Our analysis simplifies the rich description we have provided. However, we think the simplification is worthwhile in order to highlight the important, practical relevance of the relationships among actions, resources, and frameworks. To do this analysis, we recast the resourcing cycle pictured in Figure 1, which highlights the recursive way in which action both produces and reproduces the structural features of resource and framework and these structural features constrain and enable action. In the following analysis, we find it easier to diagram the temporal flow of the resourcing dynamic in the processes we have studied as a cascading stream of actions, resources, and frameworks (Figures 2 and 3).

The survey story is compelling partly because of the difference between what the public managers intended to happen and what did happen. The flow on the left in Figure 2 shows the cascade that the city managers and commissioners meant to generate. Acting within the framework of their understanding of technical neutrality, they intended the action of conducting the budget survey to generate the resource of "objective" information that would enable frameworks of technical neutrality and representative democracy. The managers wanted to combine their expertise about budgeting with information about the preferences of the population of the city as a whole, not just the people who routinely come to meetings, and thus to produce apolitical recommendations. The process was to be representative in two ways: it was meant to generate data from a statistically representative sample of the city's residents, and then to condense and funnel those data to elected representatives for them to take action on the community's behalf. Within the frameworks of
\end{abstract}




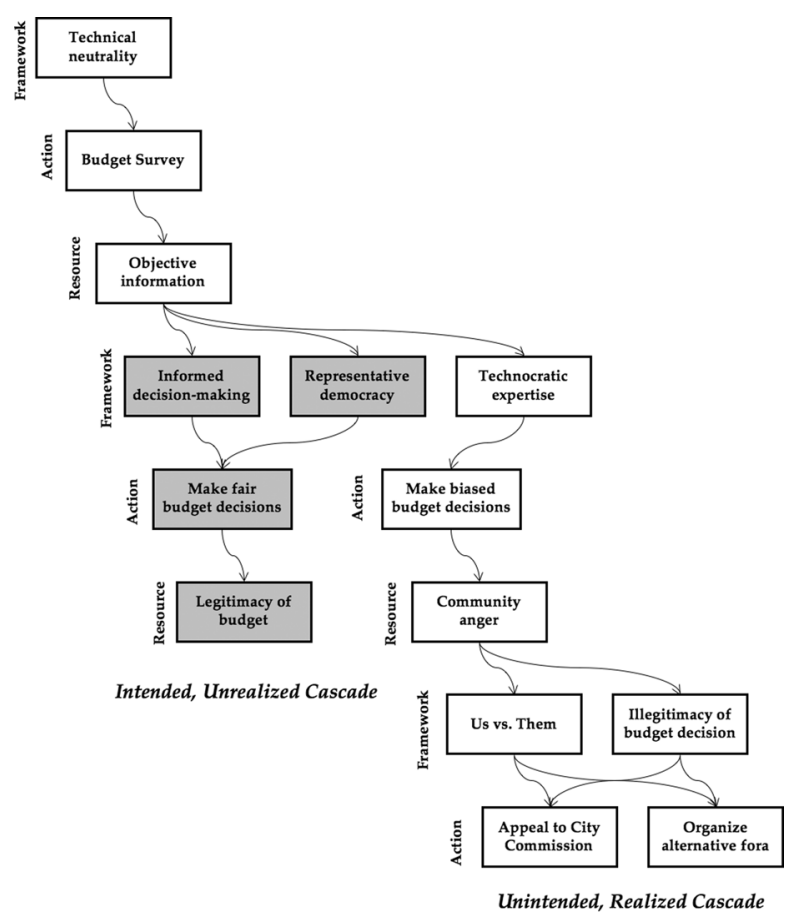

Figure 2. The Intended, Unrealized Cascade to Budget Legitimacy (Shown in Shaded Boxes), and the Unintended, Realized Cascade to Actions Challenging the Budget.

fair and informed decision-making and representative democracy, the city managers and commissioners intended to take the subsequent action of making decisions about the city budget and to produce a budget that would be widely perceived as legitimate.

Underlying this intended chain of events are some assumptions on the part of the public managers. One of these is that, as a result of other participatory decision processes including the master plan effort and the Community Oriented Government initiative, the public managers knew a lot about what was important to the residents and had developed a meaningful level of trust with community members by demonstrating their commitment to a community-based approach to decision making. In their eyes, the survey extended this commitment by including more participants than could be included in more time-intensive processes. Another assumption is that through the survey they could add relevant information to what they already knew. The desired legitimacy never materialized, however. The managers had hoped that the "objective" quality of the survey would both provide them with a sense of city residents' preferences and justify the decisions they ultimately made. It is not clear that it did the former. It certainly did not do the latter. The desired cascade towards legitimate budgeting depicted in Figure 2 is not the dominant resourcing cycle that resulted from the way participation was organized through the surveys. 


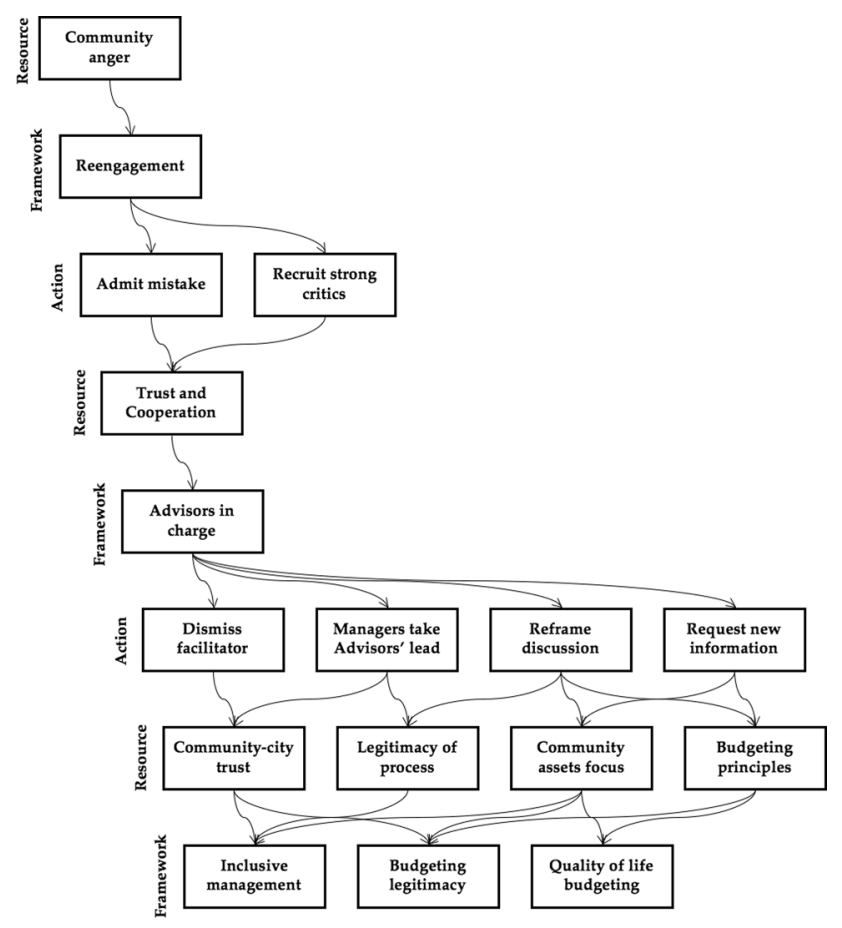

Figure 3. The Reengagement Cascade, Which Mobilized Anger to Revitalize Inclusive Management.

Ensuing from the budget survey were action-resource-framework cascades that were not at all what the city managers had intended. Among many community members, the managers' use of survey information energized a framework of technocratic expertise, with a decidedly negative connotation. Some community members felt that the preset structure of the survey indicated that staff members already knew what kinds of budgeting decisions they would make, and read the actions that emerged as biased decisions reflecting the will of the city managers rather than the will of the community. The decisions did not generate a resource of trust of city managers being appropriate decision makers about the budget. Instead, they created another potential resource that they had not intended to create: community anger. (Anger had also resulted from the survey process, but we do not know what would have happened with that anger if the information had, for instance, simply been discarded.)

The key juncture in this analysis is how the community anger resourced two very different frameworks and subsequent cascades. In the first, in Figure 2, community anger fueled a framework that the budget decision-making process and outcomes were illegitimate, and an "Us versus Them" framework for community action against the government. Operating in these frameworks, community members took 
actions of two different sorts: they appealed to the City Commissioners to reject the city managers' budget recommendations, and they created their own participatory processes that enabled them to have a fuller discussion of the issues implicit in the budget. The actions of the activated community energized a sense of community engagement and empowerment, but in a mode that oriented action towards fighting back against the senior city staff members. This oppositional orientation is part of what makes participatory efforts difficult for city staff members. The story of local governments taking a misstep and experiencing a backlash of anger that appears to feed on itself is familiar. This is a commonplace cascade.

We find the next stage of the story, however, unusual and enlightening. In this cascade, shown in Figure 3, the community anger instead resourced city managers' orientation to a reengagement framework. The managers had a longstanding philosophy of encouraging participation, and the community's anger signaled to them that they had misstepped. Rather than enacting Us vs. Them dynamics and illegitimate decision making, they wanted to reengage the community. Their actions to do so are noteworthy because they enlisted a resource - anger - that had also resourced opposition. The actions the managers took were key to remobilizing the community's anger away from opposition and towards reengagement. The city managers enacted their new framework by apologizing for having acted without sufficient public discussion and by appointing the most vocal critics as advisors. These efforts created a little bit of trust and willingness to explore possibilities to work together.

The next actions that city managers and budget advisors took enacted a framework in which the community members were in charge and the city managers acted as facilitators. The city managers supported the advisors' decisions to dismiss their facilitator and take charge of the process. The advisors reframed the budgeting problem by considering what kind of city they wanted Grand Rapids to be, and consequently requested different kinds of information than they had been given, which the managers provided. Ultimately the legitimacy of the budgeting process and decisions that the city managers had sought in their initial efforts emerged as a potential resource because of these new actions. Other potential resources that emerged were increased trust between community members and the city staff, recognition of community assets, and principles for guiding budget decisions. These potential resources then energized a variety of frameworks, including community quality of life as the framework for budgeting, budgeting legitimacy, and revitalizing inclusive management as a framework for ongoing action.

The effort to reengage appears to have been effective, though it was not a foregone conclusion that it would be. There was certainly a risk that the effort would not work. The risk, however, should be viewed in the context of other options. The managers might have enacted a framework of denying the legitimacy of the anger, perhaps by pointing out that the vocal critics were a minority of the population and, in that sense, less representative than the survey respondents, or by suggesting that the critics' complaints had less objectivity because they did not have as much information as the city officials. Another framework would be to pretend that everything was fine, ignoring the anger. 
Such tactics might have quieted some critics, but it also seems likely that they would have further fueled the Us versus Them framework. Returning to the water cascade analogy we introduced above, it is unlikely that the managers could have stopped up the flow of anger more than temporarily. While the city managers might have prevailed in asserting their role as decision makers in this particular decision, their actions would have had consequences for their overall management objectives, including their meta-framework of inclusive management. It allowed managers to recognize that they were not effectively enacting their commitment to inclusion when the community was angry about their actions during the budgeting process. The reengagement cascade was thus successfully oriented towards revitalizing inclusive management as a framework for ongoing action, one of the outcomes of the process shown at the bottom of Figure 3.

\section{DISCUSSION}

Analyzing the flow of events as we have done by following streams of actions, resources, and frameworks is painstaking. However, we believe that the effort yields both theoretical and practical contributions. Theoretically, it adds to the growing literature on resourcing in practice and on redefining the nature and importance of resources. As a result of this reconceptualization, we are also able to make a contribution to the literature on framing, a literature important to the public management field as well as to the social sciences more generally. Our contributions to the practice of public management build on these theoretical contributions.

\section{Identifying Resources}

Our case contributes to the development of resourcing theory and our understanding of resourcing in practice. It provides a vivid example of the integral connection between actions, resources, and frameworks even as our analysis separates them. While we have identified specific aspects of the flow as action resource or framework, these elements are not innately one or another of the components of the actions-resources-frameworks cycle, but rather each of them as they are constituted in practice in a specific moment and from a particular perspective. Participation, for example, can be understood as any one of the elements. It can be understood as action (e.g., organizing meetings and taking in input), as resource (e.g., as a source of new information, community buy-in, or legitimacy), and as framework (e.g., making decisions with the community rather than technocratically). The identification of specific actions, resources, and frameworks depends on the specifics of the context and the analysis. In the analysis in this paper, we have adopted a level of abstraction to view the aspects of resourcing that relate to the resourcing of inclusive management, though other choices, such as the resourcing of fiscally sustainable or socially equitable budgeting allocations, are possible.

Resources in this analysis are shown to be ephemeral, not really existing until they energize a framework. As a result, resources are in some ways the most difficult element of the actions-resources-frameworks cycle to tease out and simultaneously to 
contextualize. It is, after all, only when frameworks are energized that some potential resource such as money, time, trust, anger, or information becomes a resource. In this, we are reminded of Latour's formulation with respect to power:

... when a person simply has power nothing happens and $\mathrm{s} / \mathrm{he}$ is powerless, when on the other hand an actor exerts power, it is others who take the action. It appears that power is not something one can possess - indeed it must be treated as a consequence rather than a cause of action (Latour 1986, 264).

Similarly, from the perspective of practice, assets and qualities that could be resources are only potential resources until they are used to energize one or more frameworks. Thus, resources, much like power, do not have an independent existence. This case allows us to visualize a mutually co-constitutive cycle in which the three elements are temporally coincident and conceptually interdependent. While the figures in the paper depict a cascading, temporal flow for graphic simplicity, to emphasize the energy moving forward through them, and to reflect the narrative flow of our account, underlying these graphics is a more recursive and contextdependent understanding of what actions, frameworks, and resources are. In this case, for example, community anger is both a resource for energizing frameworks of opposition or reengagement and a framework for actions to express and act upon that anger.

Another contribution to the conversation about resourcing in practice is the distinction between potential resources and resources in use. This distinction can help us think about whether and what kind of potential resources can be stockpiled and what happens when you try to use a stockpiled resource. Our case suggests that while potential resources can be developed, putting them into use is not necessarily straightforward, and it is their entering into use that makes their availability meaningful. Our case provides an example in which the public managers have taken many opportunities to engage the public in ways that have produced broad legitimacy for many of their decisions. These managers assumed that they had sufficient knowledge about the values of the community and that there was a store of trust in their decision making that would come into play in this case. The evidence on this is mixed. While the reaction to the survey suggests that any stored up trust could be quickly eroded through actions that called it into question, it seems unlikely that the reengagement process would have worked had there not been some residue of belief that the managers valued the input of the residents.

\section{Energizing Frameworks}

Our theorization and use of the term "frameworks" draws not only on structuration theory, but also on the growing social science literature regarding frames and framing. Frames emerge from institutional contexts, and they have a powerful effect on the decision making and the development of knowledge. Goffman drew our attention to frames, the tacit "schemata of interpretation" for organizing and 
understanding experience (Goffman 1974, 21). Many social scientists have since found the concept important for understanding the development of social movements and collective action (Snow and Benford 1988; Gamson 1988; Polletta 2006), as well as specific organizational and institutional decision-making processes (Vaughan 1996; Eden 2004; Abolafia 2004). Researchers have learned much about the features of frames that make them work in particular contexts (Snow and Benford 1988).

We add to this picture in two ways. First, we highlight the effects of action on frameworks. In the recursive relationship between structure and action, the literature on framing has tended to focus on the way that frameworks constrain and enable action (Jasanoff 2005; Polletta and Lee 2006). Vaughan (1996), for instance, showed how the different frames of engineers and managers in the years leading up to the Space Shuttle Challenger disaster prevented information from being understood as relevant. To the extent that people focus on the role of actions in creating frameworks, these are intentional moves that promote a particular interest. Abolafia (2004) presents a conscious, or at least motivated, use of frames when he shows the interpretive moves made in the promotion of and resistance to a reframing of monetary policy by the Federal Reserve Board in 1982. Lakoff has pointed out the power of frames as devices for persuasion and schemata for interpretation in political debates (Bai 2005; Lakoff 2002). Frameworks in these cases are presented as cause rather than consequence. Given the recursive nature of the relationship between structure and action, frames are both cause and consequence. Our analysis helps us show how taking action is important to creating and energizing frameworks.

In our case, public managers and community members take actions that energize frameworks by bringing potential resources into use. While the sequence of events that preceded the managers' actions were important, they did not determine the events that followed as has, at times, been proposed by people concerned with path dependence (cf. Mahoney 2000; Sydow, Schreyögg, and Koch 2005). Eden's (2004) analysis of the frame for assessing nuclear explosion damage shows a dynamic similar to ours. Her research depicts how the actions taken by people promoting a blast framework or a fire framework for assessing nuclear damage provided resources (e.g., predictability, knowledge, metrics) that energized these frameworks (Eden 2004; Feldman and Pentland 2008). Thus, our research and Eden's provides a new understanding of the dynamics of path dependence and shows the importance of agentic action in creating and recreating the frames that constrain and enable action.

Second, our case illustrates the ability to energize a framework by positioning it to take advantage of potential resources. The community anger could have continued to fuel the Us versus Them framework if the public managers had not created and put considerable effort into the reengagement frame as an alternative frame that the anger could resource. Among senior public managers in Grand Rapids, inclusive management is an important way of knowing, or meta-framework, that guided them to position frameworks to bring resources into play in certain ways. In the years leading up to the budget survey, the city staff and community members had developed high expectations for inclusive management. The anger was partly a response to the budgeting survey seeming to violate that framework. The city managers 
wanted to restore inclusiveness by reengaging the public. However, the framework for reengagement was only a possibility until the managers positioned it to take advantage of the resources at hand. By appointing vocal critics to be budget advisors, they provided an alternate venue for the community anger to play out, a venue in which the anger could be combined with other resources from the city manager's office.

Similarly, the actions of city managers and community budget advisors brought the framework we identify as "quality of life budgeting" in Figure 3 into being and energized it when they responded to community outrage over the impression that city managers and politicians were viewing the city as a charity case rather than an asset. Asking "What kind of city do you want this to be?" enabled new possibilities for recognizing and bringing resources into play. It did not supplant the question of how the city should allocate its diminishing budget, but it did reorient attention to recognizing and cultivating community assets in addition to the need to cut expenditures.

Other scholars have noted the availability of multiple frameworks for making sense of particular situations (Sewell 1992; Swidler 2001) and the ability of public managers to use this availability (Thacher 2001). In Grand Rapids, multiple frameworks of exclusion coincided in the public's interpretation of the initial budgeting cycle. The resourcing perspective provides a deeper understanding of the dynamic and its significance. We have focused our analysis on reframing citizens' anger over being excluded from the budgeting decision-making process. Community members were also angry over socially exclusive budgeting outcomes, notably the closure of public pools serving low-income households. The managers and commissioners dovetailed these frameworks of exclusion - and turned the anger towards energizing a new framework of inclusion - by apologizing simultaneously for the exclusiveness of the process and its outcomes and by appointing advisors to guide them on both counts. Public managers can affect the framing of situations by moving various frameworks around a flow of potential resources through communication and other actions.

\section{Inclusive Management as a Meta-Framework}

These contributions to theory are important because the action-resource-framework cycle gives us new ways of thinking about public management interventions. If we conceptualize inclusive management as a way of knowing or meta-framework (Feldman et al. 2006), inclusive management becomes a way of thinking about what one wants to achieve through the action-resource-framework cycle. Resourcing is always productive, but it is not inherently positive in a normative sense. It can also operate in nefarious ways. Inclusive management provides a way of thinking about and talking about the resourcing choices being made as people engage in the work of public management. Olson (2007) has made a similar argument with respect to dynamic governance structures about the need for a distinction between the dynamic process and the direction of the process.

This way of thinking about inclusive management makes clear that evoking a framework of participation is not the same as resourcing inclusive management. 
Efforts to pacify or herd stakeholders may use participation and be billed as empowerment in the hopes that people will feel as if they are having an influence (Arnstein 1969; Fineman 2006). We suggest that this is not an example of a participation framework resourcing something darker, but a manipulative framework being advertised as something that it is not. Sorting through such inconsistencies is one of the ways that the resourcing perspective is useful. Thinking about whether participation is good implies thinking about what it is good for (what frameworks it energizes). The resources and frameworks are always available. The challenge for managers who wish to use participation inclusively, then, is to mobilize these resources and frameworks in inclusive ways. As our case shows, one way managers can accomplish this is by creating and rearranging frameworks to enroll the resources in desired frameworks and actions.

One of the core skills of inclusive managers that we have observed in Grand Rapids is their awareness of resourcing. Aiming for inclusion has oriented the way that they have perceived potential resources and how they have brought them into use. There have been missteps when they did not energize the frameworks they had intended. Inclusive management, however, has brought potential resources as diverse-and as potentially divisive - as community anger and trust, surpluses and shortfalls of money, and citizens' contesting opinions together in ways that open up opportunities for deliberation and collaboration, draw strength from the variety of perspectives in the community, and expand opportunities for continuing efforts to build community engagement. Grand Rapids managers' inclusive management meta-framework has enabled them to broaden their range of potential resources and to recognize, for instance, that community anger can be useful to community engagement when a structure is provided for doing so.

For public managers elsewhere, the Grand Rapids example makes us aware of the importance of thinking about the effects of one's actions in context and over time, one of the principles of inclusive management. In considering participation as a tool of inclusive management, resourcing shows how participation can produce assets and qualities that can be used to fuel more or less constructive participation and to create or discourage inclusive communities of participation. Inclusive processes are opportunities to create and develop relationships among the various potential participants. These relationships can be characterized by differing levels of trust, cooperation, willingness, and candor, among other things. These characteristics influence the likelihood of working constructively in current and future problemsolving efforts.

\section{No Time Out}

Recent scholarship in organizational behavior has identified the existence of and importance of pro-activity characterized by "creative ways in which employees deliberately plan and act to influence, change, and alter their environments" (Grant and Ashford 2008, 7). This research emphasizes the agentic rather than robotic nature of action in organizations. The resourcing perspective also emphasizes the agentic quality of action, and adds that all actions influence environments, not just actions 
consciously intended to do so. This means that people need not only to be aware of what they plan and intend, but also what they produce.

Resourcing shows that frameworks are energized through the actions we take and that resources cannot necessarily be contained within a specific topic or timeframe. The effects of actions accumulate or dissipate across issues and over time. In Grand Rapids, public managers had developed the inclusive management meta-framework through a variety of efforts, most noticeably the master plan effort, which had garnered great participation, attention, and pride. The energy in the inclusive management meta-framework decreased as a result of the budget survey and increased again through the enactment with the advisors of the reengagement framework. The expectations developed by other inclusive processes were responsible for some of the reaction to the survey: the residents expected better and knew that it was possible to organize processes that would make use of their expertise. At the same time, these expectations as well as the patterns of interaction developed in other processes may have made it easier to sustain inclusive management as a way of knowing when the city managers made efforts to reengage.

Participatory processes and other efforts at inclusion are sometimes enacted as if they are independent of other interactions. While public managers know that circumstances beyond their control often influence the context for doing their work, our analysis suggests that part of what is within their control is the consistency of the frameworks they are trying to resource. Specifically, reorienting official activities to promote inclusive, constructive relationships can develop potential resources of trust, cooperation, information, and willingness that can be brought into play in each specific inclusive process. This case shows that when people make mistakes, the general consistency of the orientation can be important to recovering from such mistakes. When public managers act, they enact choices about what frameworks to energize. There is no time out from this dynamic.

\section{Task as Resource}

Tasks are, from this resourcing perspective, an important opportunity for people to create resources and may even be seen as resources in themselves. In our case, the task was budgeting, and the various ways that city managers organized it resourced different frameworks. In the introduction, we identified the third hallmark of inclusive management to be building an ongoing community of participation by including the public in a continuous stream of issues. When budgeting was organized primarily around producing budget decisions, the continuity of the process was disrupted and potential resources that could have energized the development of community instead energized other frameworks. By contrast, when Grand Rapids managers organized the budgeting task as part of a continuous process of community building, they were able to reap the consequences of earlier actions, including those the public had found unsatisfactory, to resource ongoing engagement. Undertaking the tasks of government as opportunities to create an ongoing community of participation is fundamental to inclusive management as a way of knowing. Without understanding the tasks of government as opportunities to create this community, the Grand Rapids 
managers would be starting over again with each new task, missing opportunities for a flow of energy between them.

What a task is and what it can do depends on how it is used, or how it is incorporated into practice. Tasks are actions in that people do things. When people propose a budget, for instance, they analyze data, they write documents, and they make presentations. They may also organize public meetings. Tasks are also frameworks. They provide a frame of reference for the actions taken, making sense of and legitimating these actions as well as actions not taken. Tasks are seldom thought of as a resource. Treating a task as a resource involves asking, "How can this task energize the framework I want to promote?" rather than just asking, "How can I accomplish this task?" or "What resources do I need to do this task?"

Asking how the task can energize the framework that a public manager wants to promote has important consequences for management. From this perspective, accomplishing the task becomes secondary, not in the sense that it is unimportant, but in the sense of a reversal of figure and ground. Accomplishing the task, indeed accomplishing it well, is often essential for promoting the frameworks that can be energized through the process of accomplishing the task. However, simply accomplishing the task is no longer enough. Thus, viewing the budgeting task as a resource for the community-building framework is different from saying that one of the goals of the budgeting task is to build community. Indeed, seeing budgeting and community building as goals places them in tension with one another, as if community building could be sacrificed in order to accommodate the budgeting goal. If community building is an important framework being resourced through the budgeting task, however, it becomes important to accomplish the task in a way that encourages community building to take place. Meeting the constraints of the budgeting task, then, is a means to the end of building community by generating the sense of being able to solve problems together.

\section{CONCLUSION}

Understanding the action-resource-framework cycle enables researchers and public managers to think more clearly about the relationship between the actions public managers take and the frameworks they promote in the communities and problems they work with. This ethnographic study of budgeting processes in Grand Rapids explores a case in which public participation is an important part of creating a problem-solving community. However, understanding the interdependence of frameworks, resources, and actions allows us to recognize that inclusive efforts are not discrete events, but are related to other managerial actions across topics and over time, including, but not limited to, public participation efforts. Nor is there any reprieve from the implications of managerial actions - technocratic, participatory, or otherwise - for building an inclusive community. Resourcing makes us more aware of the contextualization of each specific public engagement effort as it relates to the overall development of the relationship with officials and government agencies. 
We find that inclusive management is a way of knowing which creates an overarching framework within which public managers recognize potential resources and use resourcing to influence the ability of residents and officials to work together to solve public problems. They use conflicts, trust, and the tasks accomplished through participation as resources for energizing inclusive governance. Another potential outcome of understanding the action-resource-framework cycle is the transformation of tasks from things that need to be done to opportunities to build constructive relationships. Tasks themselves can be used as resources, and conceptualizing them as resources resituates the role of participation in accomplishing them.

\section{ACKNOWLEDGEMENTS}

This paper, which is an equal collaboration between the two authors, was originally prepared for the National Public Management Association Conference in Tucson, Arizona, held October 25-27, 2007. We thank the participants in this study who generously contributed their thoughts and time, and Scott Byrd, Herlin Chien, Alice Diebel, Heather Goldsworthy, Helen Ingram, Steve Kelman, Anne Khademian, Guillermo Narváez, Francesca Polletta, Renee Rottner, Jonas Sprogøe, Anne Taufen Wessels, and two anonymous reviewers for helpful suggestions. This research was supported by grants from the Center for Organizational Research and Center for the Study of Democracy at the University of California, Irvine, and from the National Science Foundation, under grant no. 0712876.

\section{NOTE}

1. In this paper, we prefer the term framework to frame or schema. We recognize that the three terms have related lineages in the academic literature, but they have somewhat different meanings. Schema has the closest connection to the structuration theory that we draw upon, as Sewell (1992) suggested this term in discussing the distinction between rules and resources that Giddens (1984) proposed as constituting structure. Framework, however, has more meaning in ordinary language. Frames and framing as introduced by Goffman (1974), discussed above, are close to what we mean by framework. However, framework implies more dynamism than frame does in everyday use and is thus more appropriate to our theorization of resourcing.

\section{REFERENCES}

Abbott, A. 2004. Methods of Discovery: Heuristics for the Social Sciences. New York: W.W. Norton.

Abers, R. 2000. Inventing Local Democracy: Grassroots Policy in Brazil. Boulder, CO: Lynne Rienner Publishers.

Abolafia, M. Y. 2004. "Framing Moves: Interpretive Politics at the Federal Reserve." Journal of Public Administration Research and Theory 14: 349-370.

Agar, M. H. 1986. Speaking of Ethnography. Thousand Oaks, CA: Sage.

Aleshire, R. A. 1970. "Planning and Citizen Participation - Costs, Benefits, and Approaches." Urban Affairs Quarterly 5: 369-393. 
Altheide, D. L. and J. M. Johnson. 1994. "Criteria for Assessing Interpretive Validity in Qualitative Research.” Pp. 485-499 in N. K. Denzin and Y. S. Lincoln, eds., Handbook of Qualitative Research, Thousand Oaks, CA: Sage.

Anderson, K. and D. C. Jack. 1991. "Learning to Listen: Interview Techniques and Analyses." Pp. 11-26 in S. Berger and D. Patai, eds., Women's Words: The Feminist Practice of Oral History. New York: Routledge.

Arnstein, S. 1969. "A Ladder of Citizen Participation." Journal of the American Institution of Planners 35: 216-24.

Bai, M. 2005. "The Framing Wars." The New York Times Magazine, July 17, 2005, $38 \mathrm{ff}$.

Barney, J. B. 1991. "Firm Resources and Sustained Competitive Advantage." Journal of Management 17: 99-120.

Barney, J. B. 2001. "Is the Resource-Based 'View' a Useful Perspective for Strategic Management Research? Yes." Academy of Management Review 26: 41-56.

Beard, V. A. 2005. "Individual Determinants of Community Participation in Indonesia." Environment and Planning C: Government and Policy 23: 21-39.

Bekkers, R. 2005. "Participation in Voluntary Associations: Relations with Resources, Personality, and Political Values." Political Psychology 26: 439-454.

Benhabib, S., ed. 1996. Democracy and Difference: Contesting the Boundaries of the Political. Princeton, NJ: Princeton University Press.

Bradshaw, B. 2003. "Questioning the Credibility and Capacity of Community-Based Resource Management." Canadian Geographer 47: 137-150.

Brady, H. E., S. Verba, and K. L. Schlozman. 1995. "Beyond SES: A Resource Model of Political Participation." American Political Science Review 89: 271-294.

Bryson, J. M., F. Ackerman, and C. Eden. 2006. "Putting the Resource-Based View of Strategy and Distinctive Competencies to Work in Public Organizations." Public Administration Review 67: 702-717.

Carron, C. G. with contributions by K. L. Ames, J. D. Kleiman, and J. Lefever. 1998. Grand Rapids Furniture: The Story of America's Furniture City. Grand Rapids, MI: Public Museum of Grand Rapids.

City of Grand Rapids. 2005. City of Grand Rapids - Community Budget Meetings. Report of Meetings and Findings. Undated report of February 2005 community meetings, City of Grand Rapids, MI.

City of Grand Rapids. 2006. Citizen Budget Advisor's Report. Prepared by City of Grand Rapids Citizen Budget Advisors, March 27, 2006.

City of Grand Rapids. 2007. City Manager's Letter Accompanying City of Grand Rapids, Michigan, Final Fiscal Plan, Fiscal Years 2008-2012. Prepared by City of Grand Rapids City Manager's office, April 24, 2007.

Coch, L. and J. R. P. French. 1948. "Overcoming Resistance to Change." Human Relations 1: $512-532$.

Coelho, V. S. P. 2004. "Brazil's Health Councils: The Challenge of Building Participatory Political Institutions." IDS Bulletin-Institute of Development Studies 35: 33-39.

Community Research Institute. 2005. City of Grand Rapids Budget Survey. Final report, dated March 28, 2005, submitted to the City of Grand Rapids by the Community Research Institute of Grand Valley State University in Grand Rapids, MI.

Curtis, A. 1998. "Agency-Community Partnership in Landcare: Lessons for State-Sponsored Citizen Resource Management." Environmental Management 22: 563-574.

Czarniawska, B. 2004. "The 'Narrative Turn' in Social Studies.” Pp. 1-16 in B. Czarniawska, Narratives in Social Science Research. Thousand Oaks, CA: Sage. 
Dahl, R. A. 1961. Who Governs? Democracy and Power in an American City. New Haven, CT: Yale.

Delli Carpini, M. X., F. L. Cook, and L. R. Jacobs. 2004. "Public Deliberation, Discursive Participation, and Citizen Engagement: A Review of the Empirical Literature." Annual Review of Political Science 7: 315-344.

Denzin, N. K. 1978. The Research Act: A Theoretical Introduction to Sociological Methods. New York: McGraw-Hill.

DeSanctis, G. and M. S. Poole. 1994. "Capturing Complexity in Advanced Technology Use: Adaptive Structuration Theory." Organization Science 5: 121-147.

Dewey, J. 1926/1988. "Search for the Great Community" from The Public and Its Problems. Pp. 325-350 in J. A. Boysdston, ed., John Dewey: The Later Works, 1925-1953. Vol. 2, 1925-1927. Carbondale, IL: Southern Illinois University Press.

Diamond, L. and S. Tsalik. 2001. "Size and Democracy: The Case for Decentralization." Pp. 117-160 in L. Diamond, ed., Developing Democracy: Toward Consolidation. Baltimore: John Hopkins Press.

Dryzek, J., ed. 1990. Discursive Democracy: Politics, Policy and Political Science. Cambridge, UK: Cambridge University Press.

Eden, L. 2004. Whole World on Fire: Organizations, Knowledge, and Nuclear Weapons Devastation. Ithaca, NY: Cornell University Press.

Edwards, B. and J. D. McCarthy. 2004. "Resources and Social Movement Mobilization." Pp. 116-152 in D. A. Snow, S. A. Soule, and H. Kriesi, eds., The Blackwell Companion to Social Movements, Malden, MA: Blackwell.

Eisenhardt, K. M. 1989. "Building Theories from Case Study Research." Academy of Management Review 14: 532-550.

Eisenhardt, K. M. and J. A. Martin. 2000. "Dynamic Capabilities: What Are They?" Strategic Management Journal 21: 1105-1121.

Ely, R. J. and D. A. Thomas. 2001. "Cultural Diversity at Work: The Effects of Diversity Perspectives on Work Group Processes and Outcomes." Administrative Science Quarterly 46: 229-273.

Emerson, R. M., R. I. Fretz, and L. L. Shaw. 1995. Writing Ethnographic Fieldnotes. Chicago: University of Chicago Press.

Eschenfelder, K. R. 2004. "Behind the Web Site: An Inside Look at the Production of Web-Based Textual Government Information." Government Information Quarterly 21: 337-358.

Feldman, M. S. 1995. Strategies for Interpreting Qualitative Data. Thousand Oaks, CA: Sage.

Feldman, M. S. 2004. "Resources in Emerging Structures and Processes of Change." Organization Science 15: 295-309.

Feldman, M. S. and A. M. Khademian. 2000. "Managing for Inclusion: Balancing Control and Participation." International Public Management Journal 3: 149-167.

Feldman, M. S. and A. M. Khademian. 2003. "Empowerment and Cascading Vitality." Pp. 343-358 in K. S. Cameron, J. E. Dutton, and R. E. Quinn, eds., Positive Organizational Scholarship. San Francisco: Berrett-Koehler.

Feldman, M. S. and A. Khademian. 2007. "The Role of the Public Manager in Inclusion: Creating Communities of Participation." Governance 20: 305-324.

Feldman, M. S., A. M. Khademian, H. Ingram, and A. S. Schneider. 2006. "Ways of Knowing and Inclusive Management Practices." Public Administration Review 66: 89-99.

Feldman, M. S. and B. T. Pentland. 2008. "Routine Dynamics." Pp. 302-315 in D. Barry and H. Hansen, eds., New Approaches in Management and Organization. Los Angeles: Sage. 
Feldman, M. S., K. Sköldberg, R. N. Brown, and D. Horner. 2004. "Making Sense of Stories: A Rhetorical Approach to Narrative Analysis." Journal of Public Administration Research and Theory 14: 147-170.

Fineman, S. 2006. "On Being Positive: Concerns and Counterpoints." Academy of Management Review 31: 270-291.

Flyvbjerg, B. 1998. Rationality and Power: Democracy in Practice. Chicago: University of Chicago Press.

Forester, J. 1989. Planning in the Face of Power. Berkeley: University of California Press.

Fung, A. and E. O. Wright. 2003. "Thinking About Empowered Participatory Governance." Pp. 3-42. in A. Fung and E. O. Wright, eds., Deepening Democracy: Institutional Innovations in Empowered Participatory Governance. New York: Verso.

Gamson, W. 1988. "Political Discourse and Collective Action." International Social Movement Research 1: 219-244.

Garfinkel, H. 1967. Studies in Ethnomethodology. Cambridge, UK: Polity.

Geertz, C. 1973. "Thick Description: Toward an Interpretive Theory of Culture." Pp. 3-30 in C. Geertz, The Interpretation of Cultures. New York: Basic Books.

Giddens, A. 1984. The Constitution of Society. Los Angeles: University of California Press.

Glaser, B. and A. Strauss. 1967. The Discovery of Grounded Theory: Strategies for Qualitative Research. Chicago: Aldine.

Goffman, E. 1974. Frame Analysis: An Essay on the Organization of Experience. Boston: Northeastern University Press.

Goldfrank, B. 2007. "The Politics of Deepening Local Democracy: Decentralization, Party Institutionalization, and Participation." Comparative Politics 39: 147-168.

Goodenough, W. H. 1970. "Describing a Culture.” Pp. 104-119 in W. H. Goodenough, Description and Comparison in Cultural Anthropology. Cambridge, UK: Cambridge University Press.

Grant, A. M. and S. J. Ashford. 2008. "The Dynamics of Proactivity at Work.” Research in Organizational Behavior 28: 3-34.

Green, G. P. and A. Haines. 2002. Asset Building and Community Development. Thousand Oaks, CA: Sage.

Grisez Kweit, M. and R. W. Kweit. 2007. "Participation, Perception of Participation, and Citizen Support." American Politics Research 35: 407-425.

Guerra, E. 2003. "Citizenship Knows No Age: Children's Participation in the Governance and Municipal Budget of Barra Mansa, Brazil." Environment and Urbanization 14: 71-84.

Healey, P. 1997. Collaborative Planning: Shaping Places in Fragmented Societies. Vancouver: UBC.

Healey, P. 2003. "Collaborative Planning in Perspective." Planning Theory 2: 101-123.

Heritage, J. 1984. Garfinkel and Ethnomethodology. New York: Polity.

Hobfoll, S. E. 2002. "Social and Psychological Resources and Adaptation." Review of General Psychology 6: 307-24.

Holstein, J. and J. Gubrium. 1995. The Active Interview. Thousand Oaks, CA: Sage.

Howard-Grenville, J. A. 2007. "Developing Issue-Selling Effectiveness over Time: Issue Selling as Resourcing." Organization Science 18: 560-577.

Innes, J. E. and D. E. Booher. 1999. "Consensus Building and Complex Adaptive Systems: A Framework for Evaluating Collaborative Planning." Journal of the American Planning Association 65: 412-424.

Irvin, R. A. and J. Stansbury. 2004. "Citizen Participation in Decision Making: Is It Worth the Effort?" Public Administration Review 64: 55-65. 
Janesick, V. J. 1994. “The Dance of Qualitative Research Design: Metaphor, Methodolatry, and Meaning." Pp. 199-219 in N. K. Denzin and Y. S. Lincoln, eds., Handbook of Qualitative Research, Thousand Oaks, CA: Sage.

Jasanoff, S. 2005. Designs on Nature: Science and Democracy in Europe and the United States. Princeton, NJ: Princeton University Press.

Jenkins, J. C. 1983. "Resource Mobilization Theory and the Study of Social Movements." Annual Review of Sociology 9: 527-553.

Kaldecek, J. M. 1996. "Intergovernmental Cooperation in Metropolitan Grand Rapids, Michigan." DPA diss., Western Michigan University, Kalamazoo, MI.

Kirk, J. and M. L. Miller. 1986. Reliability and Validity in Qualitative Research. Thousand Oaks, CA: Sage.

Kirkman, B. L. and B. Rosen. 1999. "Beyond Self-Management: Antecedents and Consequences of Team Empowerment." Academy of Management Journal 42: 58-74.

Klandermans, B. 1984. "Mobilization and Participation: Social-Psychological Expansions of Resource Mobilization Theory." American Sociological Review 49: 583-600.

Klein, H. K. 1999. "Tocqueville in Cyberspace: Using the Internet for Citizen Associations." Information Society 15: 213-220.

Koontz, T. M. and E. M. Johnson. 2004. "One Size Does Not Fit All: Matching Breadth of Stakeholder Participation to Watershed Group Accomplishments." Policy Sciences 37: 185-204.

Krueger, B. S. 2002. "Assessing the Potential of Internet Political Participation in the United States: A Resource Approach." American Politics Research 30: 476-498.

Kumar, S. 2002. "Does 'Participation' in Common Pool Resource Management Help the Poor? A Social Cost-Benefit Analysis of Joint Forest Management in Jharkhand, India." World Development 30: 763-782.

Lake, R. L. and R. Huckfeldt. 1998. "Social Capital, Social Networks, and Political Participation." Political Psychology 19: 567-584.

Lakoff, G. 2002. Moral Politics: How Liberals and Conservatives Think. 2nd ed. Chicago: University of Chicago Press.

LaMore, R. L. and F. Supanich-Goldner. 2000. "John Logie and Intergovernmental Relations in Grand Rapids, Michigan." Pp. 49-64 in J. R. Bowers and W. C. Rich, eds., Governing Middle-Sized Cities: Studies in Mayor Leadership. Boulder, CO: Lynne-Rienner.

Langley, A. 1999. "Strategies for Theorizing from Process Data." Academy of Management Review 24: 691-710.

Latham, G. P., M. Erez, and E. A. Locke. 1988. "Resolving Scientific Disputes by the Joint Design of Crucial Experiments by the Antagonists: Application to the Erez-Latham Dispute Regarding Participation in Goal Setting." Journal of Applied Psychology 73: $753-772$.

Latour, B. 1986. “The Powers of Association.” Pp. 264-280 in J. Law, ed., Power, Action, and Belief. London: Routledge.

Leblebici, H., G. R. Salancik, A. Copay, and T. King. 1991. "Institutional Change and the Transformation of Interorganizational Fields: An Organizational History of the U.S. Radio Broadcasting Industry." Admininstrative Science Quarterly 36: 333-63.

Likert, R. 1961. New Patterns of Management. New York: McGraw-Hill.

Lin, A. C. 1998. "Bridging Positivist and Interpretivist Approaches to Qualitative Methods." Policy Studies Journal 26: 162-180.

Locke, K. 2001. Grounded Theory in Management Research. Thousand Oaks, CA: Sage. Lofland, J. and L. Lofland. 1995. Analyzing Social Settings. Belmont, CA: Wadsworth. 
Logan, T. H. n.d. Almost Lost: Building and Preserving Heritage Hill, Grand Rapids, Michigan. Traverse City, MI: Arbutus.

Mahoney, J. 2000. "Path Dependence in Historical Sociology." Theory and Society 29: $507-548$.

McGregor, D. 1960. The Human Side of Enterprise. New York: McGraw-Hill.

Miller, M. L. and J. van Maanen. 1979. “'Boats Don't Fish: People Do': Some Ethnographic Notes on the Federal Management of Fisheries in Gloucester." Human Organization 38: $377-85$.

Minkoff, D. C. 1997. "Producing Social Capital - National Social Movements and Civil Society." American Behavioral Scientist 40: 606-619.

Mohr, L. 1982. Explaining Organizational Behavior. San Francisco: Jossey-Bass.

Morrison, E. W. and F. J. Milliken. 2000. "Organizational Silence: A Barrier to Change and Development in a Pluralistic World." Academy of Management Review 25: 706-725.

Morse, N. C. and E. Reimer. 1956. "The Experimental Change of a Major Organizational Variable." Journal of Abnormal and Social Psychology 52: 120-129.

Moynihan, D. P. 2003. "Normative and Instrumental Perspectives on Public Participation Citizen Summits in Washington, DC." American Review of Public Administration 33: 164-188.

Nicolini, D. 2007. "Practices as a Site of Knowing." Presentation for the Theorizing Ways of Knowing: Beyond Interests conference, Alexandria, VA, May 18-29, 2007.

Nicolini, D., S. Gherardi, and D. Yanow, eds. 2003. Knowing in Organizations: A PracticeBased Approach. Armonk, NY: ME. Sharpe.

Olson, K. 2007. "Constructing Citizens." Journal of Politics 70: 1-14.

Orlikowski, W. J. 1992. "The Duality of Technology: Rethinking the Concept of Technology in Organizations." Organization Science 3: 398-427.

Orlikowski, W. J. 2000. "Using Technology and Constituting Structures: A Practice Lens for Studying Technology in Organizations." Organization Science 11: 404-428.

Orlikowski, W. J. 2002. "Knowing in Practice: Enacting a Collective Capacity in Distributed Organizing." Organization Science 13: 249-73.

Pentland, B. T. and M. S. Feldman. 2007. "Narrative Networks: Patterns of Technology and Innovation." Organization Science 18: 781-795.

Pfeffer, J. 1982. Organizations and Organization Theory. Marshfield, MA: Pitman Publishing.

Pfeffer, J. and G. Salancik. 1978. The External Control of Organizations: A Resource Dependence Perspective. New York: Harper and Row.

Polletta, F. 2006. It Was Like a Fever: Storytelling in Protest and Politics. Chicago: University of Chicago Press.

Polletta, F. and J. Lee. 2006. "Is Telling Stories Good for Democracy? Rhetoric in Public Deliberation After 9/11." American Sociological Review 71: 699-723.

Quick, K. S. and M. S. Feldman. 2007. "Inclusive Management: Planning 'Green Grand Rapids." Teaching case prepared for the Program on the Analysis and Resolution of Conflicts of the Maxwell School at Syracuse University. http://www.maxwell.syr.edu/ parc/eparc/cases/ inclusive-management-planning-green-grand-rapids.asp.

Rawls, J. 1971. A Theory of Justice. Cambridge, MA: Belknap.

Reich, R. B. 1998. The Power of Public Ideas. Cambridge, MA: Harvard University Press.

Renn, O., T. Webler, H. Rakel, P. Dienel, and B. Johnson. 1993. "Public Participation in Decision-Making: A 3-Step Procedure.” Policy Sciences 26: 189-214.

Richardson, R. and C. Waddington. 1996. "Allocating Resources: Community Involvement Is Not Easy." International Journal of Health Planning and Management 11: 307-315. 
Roberts, N. 1997. "Public Deliberation: An Alternative Approach to Crafting Policy and Setting Direction." Public Administration Review 57: 124-32.

Roberts, N. 2004. "Public Deliberation in an Age of Direct Citizen Participation." American Review of Public Administration 34: 315-353.

Robinson, T. E. 2006. A City Within a City: The Social and Economic Construction of Segregated Space in Grand Rapids, Michigan 1945-1975. PhD diss., University of Michigan, Ann Arbor, MI.

Rossi, J. 1997. "Participation Run Amok: The Costs of Mass Participation for Deliberative Agency Decision-Making." Northwestern University Law Review 92: 173-249.

Schneider, A. and H. Ingram. 1997. Policy Design for Democracy. Lawrence, KS: University of Kansas Press.

Sewell, W. H. 1992. "A Theory of Structure: Duality, Agency and Transformation.” American Journal of Sociology 98:1-29.

Sewell, W. H. 1996. "Three Temporalities: Toward an Eventful Sociology." Pp. 245-280 in T. McDonald, ed., The Historic Turn in the Human Sciences. Ann Arbor, MI: University of Michigan Press.

Simonsen, W. and M. D. Robbins. 2000. Citizen Participation in Resource Allocation. Boulder, CO: Westview.

Snow, D. A. and R. D. Benford. 1998. "Ideology, Frame Resonance, and Participant Mobilization." International Social Movement Research 1: 197-217.

Souza, C. 2001. "Participatory Budgeting in Brazilian Cities: Limits and Possibilities in Building Democratic Institutions." Environment and Urbanization 13: 159-184.

Spradley, J. 1979. The Ethnographic Interview. New York: Holt, Rinehart and Winston.

Spreitzer, G. M. 1996. "Social Structural Characteristics of Psychological Empowerment." Academy of Management Journal 39: 483-504.

Spreitzer, G. M. and R. E. Quinn. 2001. A Company of Leaders: Five Disciplines for Unleashing the Power in Your Workforce. Ann Arbor, MI: University of Michigan Press.

Strauss, A. and J. Corbin. 1990. Basics of Qualitative Research: Grounded Theory Procedures and Techniques. Thousand Oaks, CA: Sage.

Swidler, A. 2001. Talk of Love: How Culture Matters. Chicago: University of Chicago Press.

Sydow, J., G. Schreyögg, and J. Koch. 2005. "Organizational Paths: Path Dependency and Beyond." Paper presented at 21st EGOS Colloquium, Berlin, Germany, June 30-July $2,2005$.

Talisse, R. 2001. "Liberty, Community, and Democracy: Sidney Hook's Pragmatic Deliberativism." Journal of Speculative Philosophy 15: 286-304.

Teece, D. J., G. Pisano, and A. Shuen. 1997. "Dynamic Capabilities and Strategic Management." Strategic Management Journal 18: 509-533.

Thacher, D. 2001. "Equity and Community Policing: A New View of Community Partnerships." Criminal Justice Ethics 20: 3-16.

Thompson, J. D. 1967. Organizations in Action. New York: McGraw-Hill.

Vaughan, D. 1996. The Challenger Launch Decision: Risky Technology, Culture, and Deviance at NASA. Chicago: University of Chicago Press.

Verba, S., K. L. Schlozman, H. Brady, and N. H. Nie. 1993. "Race, Ethnicity, and Political Resources: Participation in the United States." British Journal of Political Science 23: 453-497.

Vroom, V. H. and P. W. Yetton. 1973. Leadership and Decision-Making. Pittsburgh, PA: University of Pittsburgh Press. 
Wamsley, G. and M. Zald. 1973. The Political Economy of Public Organizations: A Critique and Approach to the Study of Public Administration. Bloomington, IN: Indiana University Press.

Waste, R. J. 1986. Community Power: Directions for Further Research. Beverly Hills, CA: Sage.

Wernerfelt, B. 1984. “A Resource-Based View of the Firm.” Strategic Management Journal 5: $171-180$.

Yanow, D. and P. Schwartz-Shea, eds. 2006. Interpretation and Method: Empirical Research Methods and the Interpretive Turn. Armonk, NY: M.E. Sharpe.

Yin, R. K. 2003. Case Study Research: Design and Methods. Thousand Oaks, CA: Sage.

Young, I. M. 2000. Inclusion and Democracy. Oxford: Oxford University Press.

Zald, M. N. 1970. "Political Economy: A Framework for Comparative Analysis." Pp. 221-269 in M. N. Zald, ed., Power in Organizations, Nashville, TN: Vanderbilt University Press.

\section{ABOUT THE AUTHORS}

Martha S. Feldman (feldmanm@uci.edu) is the Johnson Chair for Civic Governance and Public Management and Professor of Planning, Policy and Design, Political Science, Management and Sociology at the University of California, Irvine. She is a Senior Editor for Organization Science and Book Review Editor for the International Public Management Journal and also serves on the editorial boards of Business Research, The Journal of Management Studies, Organization Studies, and the book series: Advances in Organization Studies and Public Administration: Criticism and Creativity. She has written 4 books and dozens of articles on the topics of organization theory, public management and qualitative research methods.

Kathryn S. Quick (kquick@uci.edu) is a PhD candidate in Planning, Policy, and Design at the University of California, Irvine, where she is completing a dissertation entitled, "The Consequences of Public Participation for Policy Outcomes and Ongoing Engagement: Experiments in Inclusive Management in Grand Rapids.” Her ethnographic research on the interventions that public managers make to enhance and diminish opportunities for civic engagement in builds upon twelve years of professional experience as a project manager in housing, social service, and environmental planning for local governments and non-governmental organizations in California and Indonesia. She is a member of the public-government research group of the Kettering Foundation. 